\title{
Environmental factors modulating the bathymetric distribution of the demographic groups of Achelous spinimanus (Crustacea)
}

\author{
Camila Hipolito Bernardo ${ }^{1}$, Veronica Pereira Bernardes ${ }^{1}$, \\ Aline Nonato de Sousa ${ }^{1}$, Gabriel Fellipe Barros Rodrigues ${ }^{1}$, \\ Thiago Elias da Silva ${ }^{1}$, Adilson Fransozo ${ }^{1}$
}

1 Group of Study on Crustacea Biology, Ecology and Culture (NEBECC), Department of Zoology, São Paulo State University (UNESP), Institute of Biosciences, Botucatu, State of São Paulo, Brazil

Corresponding author: Camila H. Bernardo (camila.hipolito@unesp.br)

Academic editor:A.M. Leal-Zanchet | Received 22 May 2018 | Accepted 21 December 2018 | Published 11 April 2019

Citation: Bernardo CH, Bernardes VP, de Sousa AN, Barros Rodrigues GF, da Silva TE, Fransozo A (2019) Environmental factors modulating the bathymetric distribution of the demographic groups of Achelous spinimanus (Crustacea). Neotropical Biology and Conservation, 14(1): 13-28. https://doi.org/10.3897/neotropical.14.e34829

\begin{abstract}
The spatio-temporal distribution of Achelous spinimanus demographic groups (juveniles, and adult males and females) and its relation with environmental factors was analyzed in the region of Ubatuba, southeastern Brazil. We performed the samplings from January to December 2000, at eight sites of different depths. A total of 402 specimens of A. spinimanus was captured. The lowest abundance of all demographic groups occurred in summer, while in winter and spring the abundance of adults was very high. Spatially, juveniles were found at 5 to $35 \mathrm{~m}$ of depth, while adults at 15 to $40 \mathrm{~m}$, but were more abundant at $25 \mathrm{~m}$. The low abundance of all demographic groups during summer is probably due to the arrival of the South Atlantic Central Water in the region, which decreased the water temperature and salinity. These changes caused the migration of A. spinimanus to more sheltered places of the bay, possibly due to more favorable environmental conditions. The high abundance of the demographic groups at $25 \mathrm{~m}$ of depth was due to its more heterogeneous sediment, and to avoid competition with other species more abundant in shallower areas. Therefore, the factors that modulate the distribution of A. spinimanus may differ depending on the ontogenetic phase.
\end{abstract}




\section{Keywords}

Seasonal migration, SACW, ecological niche, interspecific relations

\section{Introduction}

The distribution of marine decapod crustaceans is generally linked to the depth gradient, and determined by one or a set of environmental factors (sediment texture, organic matter content, bottom salinity and temperature) and biotic factors (Mantelatto et al., 1995; Fantucci et al., 2009). In addition, Guillory et al. (2001) and Andrade et al. (2014) showed that habitat selection by individuals depends on the specific physiological needs of each life cycle phase. However, understanding the distribution patterns of benthic populations is difficult due to the extension of the marine environment and the complex interactions between species and environmental factors (Shirley et al., 1990). Therefore, studies in small areas, such as coves and bays, can help to understand the interactions between these invertebrates and the environmental factors (Braga et al., 2007).

The northern coast of the State of São Paulo has a high number of bays due to its proximity to the hills of Serra do Mar (Mahiques, 1995). This conformation allowed the formation of microhabitats that favor the development and establishment of the marine biota (Negreiros-Fransozo et al., 1991). However, due to the presence of a rich biota, the Ubatuba region is intensely exploited by trawl fisheries targeting shrimps of commercial interest. Trawling is considered predatory and disturbs the benthic communities (Mantelatto et al., 2016).

The swimming crab Achelous spinimanus (LATReILle 1819) is part of the trawling bycatch fauna in Ubatuba (Fransozo et al., 2016; Mantelatto et al., 2016; Bertini et al., 2010ab). This species is considered an important element in the food chain, influencing the dynamics and organization of this environment (Bertini and Fransozo, 2004; Mantelatto and Fransozo, 1999). In addition, A. spinimanus reaches an appropriate size and its flavor is suitable for consumption, which makes it a fishing resource (Santos et al., 1995, Andrade et al., 2017). This swimming crab is distributed in the Western Atlantic, occurring from New Jersey (USA) to the State of Rio Grande do Sul (Brazil), where it is captured from the tidal zone to a depth of $90 \mathrm{~m}$ (Melo, 1996).

Achelous spinimanus has already been studied by other researchers. For instance, in the Ubatuba region (SP) Santos et al. (1994, 2000), Lima et al. (2014) and Sousa et al. (2018) studied its ecological distribution, and Santos and Negreiros-Fransozo (1999) its reproductive cycle. Branco and Lunardon-Branco (2002) reported its trophic ecology in Armação do Itapocoroy, Penha (SC). Ripoli et al. (2007) studied its population dynamics in a coastal stretch of Frade Island in Vitória (ES). De Carli et al. (2016) reported its fecundity and morphometry on the coast of São Paulo, and Andrade et al. (2017) reported its reproductive and population traits in Macaé (RJ). Despite all these studies with $A$. spinimanus, nothing is known about the spatiotemporal distribution of its demographic groups. A differential spatio-temporal 
distribution for demographic groups has been reported for other swimming crabs such as Callinectes ornatus ORdwAY 1863 (Andrade et al., 2014), Callinectes danae Smith 1869 (Barreto et al., 2006 and Antunes et al., 2015) and Arenaeus cribrarius (LAmarck 1818) (Silva et al., 2018). In view of that, we believe that A. spinimanus also shows this pattern. Thus, this study analyzed the distribution of A. spinimanus demographic groups in relation to depth, months, and environmental factors (bottom temperature and salinity, phi and organic matter) in the Ubatuba region, from January to December 2000. With this information we will expand the knowledge on the biology of A. spinimanus, and help to develop more precise management strategies. These strategies are needed since Ubatuba is under intense exploitation by artisanal shrimp fisheries and A. spinimanus is commonly caught as a bycatch.

\section{Methods}

\section{Study area}

The region of Ubatuba, in the northern coast of the state of São Paulo, southeastern Brazil, is a region of faunistic transition between tropical and subtropical regions, and thus an important area for research on crustaceans (Mantelatto et al., 2004 and Boschi, 2000). According to Pires (1992), Ubatuba is strongly influenced by three water masses: South Atlantic Central Water (SACW), with low temperature and salinity; Tropical Water (TW), with high temperature and salinity; and Coastal Water (CW), with high temperature and low salinity.

\section{Data collect}

Swimming crabs were collected monthly in the Ubatuba region with a fishing boat equipped with two double rig nets, in the period from January to December 2000. A total of eight depths $(5,10,15,20,25,30,35$ and $40 \mathrm{~m})$ were delimited and monthly trawled over a 30 -min period (about $2 \mathrm{~km}$ each) covering a sampling area of about $18.000 \mathrm{~m}^{2}$ (Figure 1). An ecobathymeter coupled with a GPS was used to record depth at sampling sites. In each depth, samples of the substratum and water from the bottom were monthly collected for analysis of environmental factors. Water was collected with a Nansen bottle in order to obtain the temperature and the salinity. Surface water was sampled also for the temperature. The temperature $\left({ }^{\circ} \mathrm{C}\right)$ was measured with a mercury thermometer and salinity (ppt) using an optical refractometer.

Sediment samples were obtained with a Van Veen grab $\left(0.025 \mathrm{~m}^{2}\right)$ to analyze sediment grain size composition and organic matter content. Sediment samples were transported to the laboratory and oven-dried at $70^{\circ} \mathrm{C}$ for $48 \mathrm{~h}$. For the analysis of grain size composition, two subsamples of $50 \mathrm{~g}$ were treated with $250 \mathrm{~mL}$ of $\mathrm{NaOH}$ solution $(0.2 \mathrm{~mol} / \mathrm{L})$ and stirred for $5 \mathrm{~min}$ to release silt and clay particles. Next, the subsamples were rinsed on a $0.063 \mathrm{~mm}$ sieve. Grain size composition fol- 


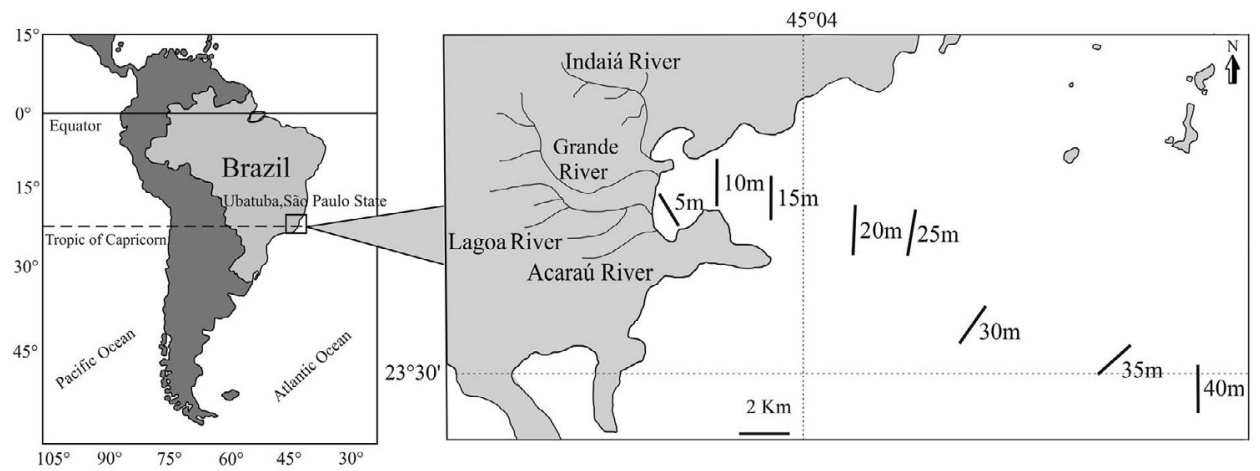

Figure 1. Location of the study region, indicating the depths sampled.

lowed the Wentworth (1922) American standard, for which sediments were sieved at: $2 \mathrm{~mm}$ (for gravel retention); $2.0-1.0 \mathrm{~mm}$ (very coarse sand); $1.0-0.5 \mathrm{~mm}$ (coarse sand); 0.5-0.25 mm (medium sand); 0.25-0.125 mm (fine sand) and 0.125-0.063 $\mathrm{mm}$ (very fine sand). Smaller particles were classified as silt and clay.

The three most quantitative important sediment grain size fractions were defined according to Magliocca and Kutner (1965): Class A - sediments in which gravel (G), very coarse sand (VCS), coarse sand (CS), and medium sand (MS) account for more than $70 \%$ of the sample weight. In Class B, fine sand (FS) and very fine sand (VFS) constitute more than $70 \%$ by of the sample weight. In Class C, more than $70 \%$ of the sediments are silt and clay $(\mathrm{S}+\mathrm{C}) . P h i$ values were calculated using the formula $p h i=-\log _{2} \mathrm{~d}$, where $\mathrm{d}=$ grain diameter $(\mathrm{mm})$, in which the following scale was obtained: $-2=p h i<-1(\mathrm{G}) ;-1=p h i<0$ (VCS); $0=p h i<1$ (CS); $1=p h i$ $<2$ (MS); $2=p h i<3$ (FS); $3=p h i<4$ (VFS); and $p h i \geq 4(\mathrm{~S}+\mathrm{C})$. From these scales, measures of central tendency were calculated in order to determine the most frequent grain size fraction in the sediment. These values were calculated from data extracted from cumulative curves of sediment frequency distribution. The values corresponding to the 16th, 50th and 84th percentiles were used to determine the mean diameter $(\mathrm{md})$ using the formula $\mathrm{md}=$ phi16 + phi50 + phi84/3 (Suguio, 1973). These three categories were further combined to form nine different groups: $\mathrm{PA}=(\mathrm{MS}+\mathrm{CS}+\mathrm{VCS}+\mathrm{G})>70 \% ; \mathrm{PAB}=$ prevalence of $\mathrm{A}$ over $\mathrm{B}(\mathrm{FS}+\mathrm{VFS}) ; \mathrm{PAC}$ $=$ prevalence of $\mathrm{A}$ over $\mathrm{C}(\mathrm{S}+\mathrm{C}) ; \mathrm{PB}=(\mathrm{FS}+\mathrm{VFS})>70 \%$; $\mathrm{PBA}=$ prevalence of $\mathrm{B}$ over $\mathrm{A} ; \mathrm{PBC}=$ prevalence of $\mathrm{B}$ over $\mathrm{C} ; \mathrm{PC}=(\mathrm{S}+\mathrm{C})>70 \%$; $\mathrm{PCA}=$ prevalence of $\mathrm{C}$ over $\mathrm{A} ; \mathrm{PCB}=$ prevalence of $\mathrm{C}$ over $\mathrm{B}$. Finally, organic matter content of sediment was estimated as the difference between initial and final ash-free dry weights of two subsamples $\left(10 \mathrm{~g}\right.$ each) incinerated in porcelain crucibles at $500^{\circ} \mathrm{C}$ for $3 \mathrm{~h}$.

\section{Laboratory procedures}

The individuals were identified according to Melo (1996), separated by sex by abdominal morphology (triangular - males, rounded - females) and the number of 
pleopods ( 2 pairs - male, 4 pairs - female). Individuals with the sealed abdomen were considered immature (IM), and those with the unsealed abdomen were considered adult. The individuals were separated into demographic groups: juveniles (immature males + immature females), adult males and adult females.

\section{Data analysis}

The normality and homoscedasticity were tested by the Shapiro Wilk and Levene tests, respectively. The environmental variables and the abundance of the demographic groups were compared between the depths and the months sampled, using the Kruskal-Wallis statistical test, complemented by Dunn's multiple comparison test (Zar, 1996). The Mann-Whitney test was performed between the surface and bottom temperatures in the months and depths. A Redundancy Analysis (RDA) was used in order to detect possible relationships between the abundance of the demographic groups and the environmental factors (bottom temperature and salinity, phi and organic matter) (Oksanen et al., 2013). The variables were considered biologically significant according to Rakocinski et al. (1996) (i.e. $\geq \pm 0.4$ ).

Two correspondence analyzes (CA) were made with the demographic groups mentioned above: one with the different depths and another with the months. The observed associations of both variables (abundance group and bathymetric distribution) and (abundance group and months) were summarized by the frequency of each cell in the table and then placed in a geometric dimensional space. The statistical significance of the values and proportion was evaluated using the chi-square test $(\chi 2)$, with simulated p-value (based on 2000 permutations) (Nenadic and Greenacre, 2007).

\section{Results}

Mean bottom temperature was $23.6 \pm 2.3^{\circ} \mathrm{C}$, ranging from 16.6 to $23.7^{\circ} \mathrm{C}$, with a significant difference between months $(\mathrm{H}=39.8$ and $\mathrm{p}<0.05)$ and between depths $(\mathrm{H}=28.7$ and $\mathrm{p}<0.05)$ (Figure $2 \mathrm{a}$ and Table 1$)$. Mean surface temperature was $23.5 \pm 2.7^{\circ} \mathrm{C}$, ranging from 18.8 to $23.5^{\circ} \mathrm{C}$, and it was significantly different between months $(\mathrm{H}=88.6$ and $\mathrm{p}<0.05)$. A thermocline was observed from January to April (Figure $2 \mathrm{a}$ and Table 1) and at depths above $15 \mathrm{~m}$ (Figure $2 \mathrm{~b}$ and Table 1). Mean salinity was $34.6 \pm 2.1$, ranging from 30 to 40 . The highest salinity was recorded in June (Figure 3a), whilst the lowest occurred in May and September (Figure 3a and Table 1$)(\mathrm{H}=62.1$ and $\mathrm{p}<0.05)$ and $(\mathrm{H}=47.0$ and $\mathrm{p}<0.05)$, respectively. The sediment at depths of 5-15 m had high phi values, characterizing a very fine sediment, and also the highest organic matter content. At $20 \mathrm{~m}$ of depth and below, phi values decreased, indicating a more heterogeneous sediment, and the organic matter decreased too (Figure 4).

A total of 402 specimens of $A$. spinimanus was collected, 28 juveniles, 105 adult males, and 269 adult females. Only juveniles were found at the shallowest sites (5-10 

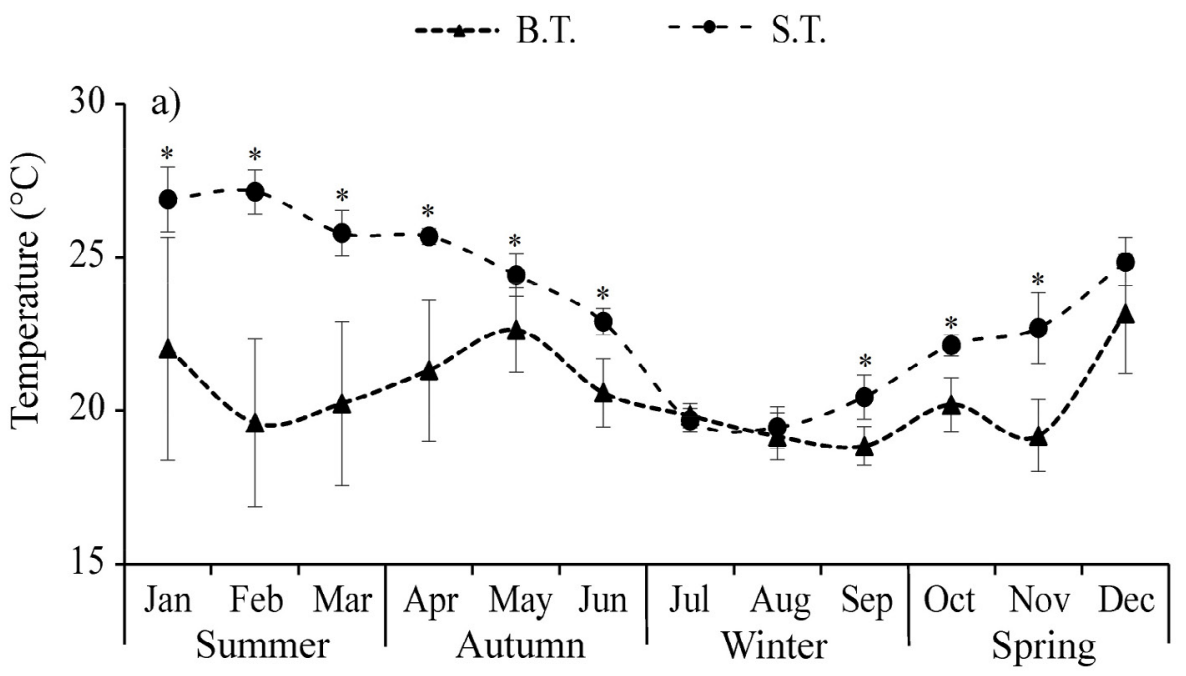

Months and Seasons

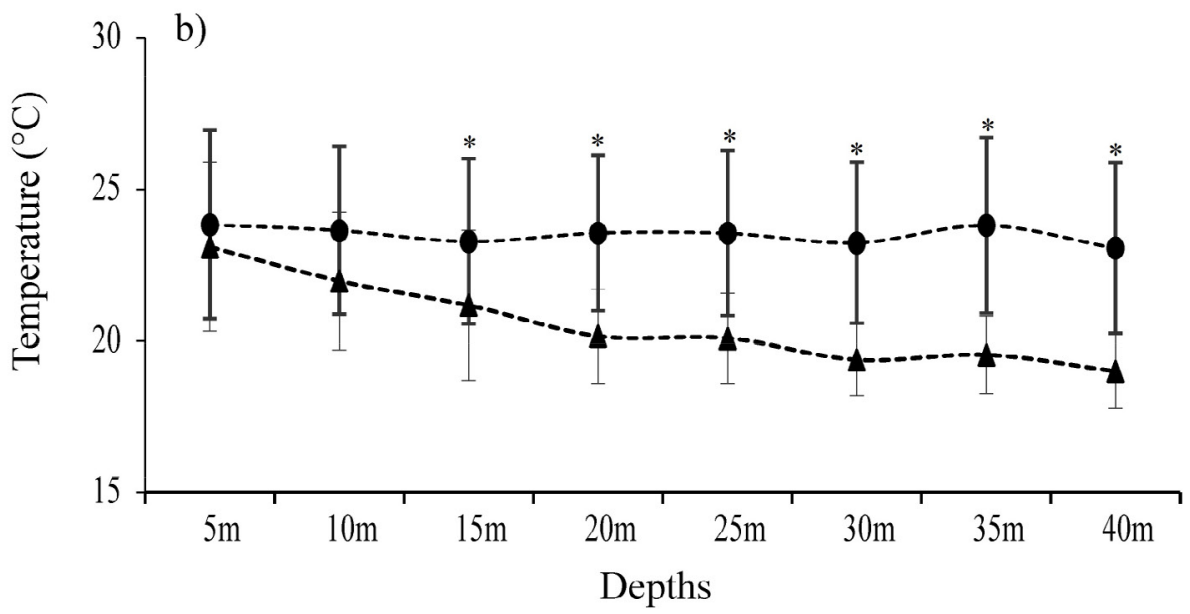

Figure 2. Mean and standard deviation of the bottom (B.T.) and surface (S.T.) temperatures sampled monthly (a) and depth (b) in the year 2000. ${ }^{*}$ Mann-Whitney test, $\mathrm{p}<0.05$.
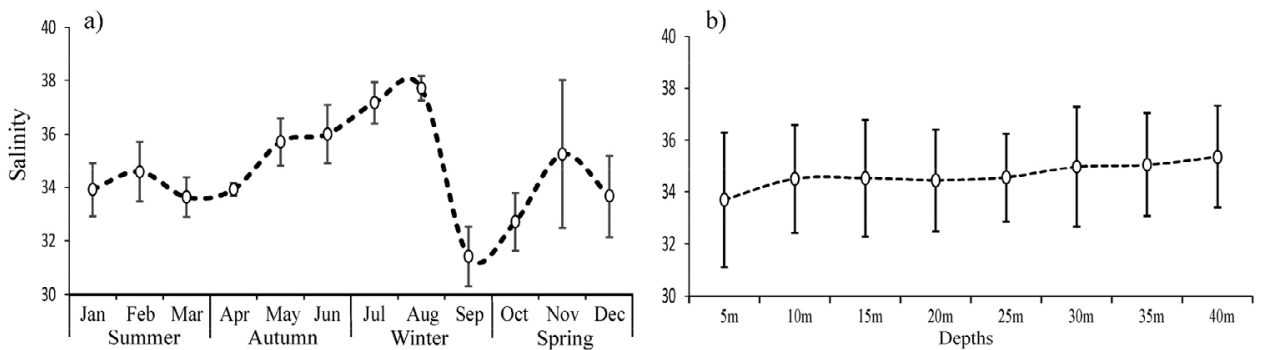

Figure 3. Mean and standard deviation of the bottom salinity sampled monthly (a) and by depth (b) in the year 2000 . 
Table 1. Mean and standard deviation $( \pm \mathrm{SD})$ of bottom temperature $(\mathrm{BT})$, surface temperature (ST) and bottom salinity (BS), recorded months and depths. Dunn test result; equal letters have no statistical difference $(\mathrm{p}>0.05)$.

\begin{tabular}{|c|c|c|c|c|c|c|}
\hline Months & $\mathrm{BT} \pm \mathrm{SD}$ & Dunn & $\mathrm{ST} \pm \mathrm{SD}$ & Dunn & $\mathrm{BS} \pm \mathrm{SD}$ & Dunn \\
\hline Jan & $22.02 \pm 3.62$ & $\mathrm{ab}$ & $26.89 \pm 1.06$ & $\mathrm{ab}$ & $33.91 \pm 1.00$ & abcdf \\
\hline Feb & $19.60 \pm 2.73$ & $\mathrm{a}$ & $27.14 \pm 0.72$ & $\mathrm{a}$ & $34.58 \pm 1.12$ & abcfg \\
\hline Mar & $20.22 \pm 2.66$ & $\mathrm{a}$ & $25.79 \pm 0.74$ & $a b c$ & $33.62 \pm 0.74$ & bcd \\
\hline Apr & $21.31 \pm 2.29$ & $\mathrm{ab}$ & $25.68 \pm 0.25$ & $a b c$ & $33.91 \pm 0.23$ & abcd \\
\hline May & $22.62 \pm 1.37$ & $\mathrm{~b}$ & $24.42 \pm 0.69$ & bce & $35.70 \pm 0.88$ & aefg \\
\hline Jun & $20.58 \pm 1.10$ & $a b$ & $22.89 \pm 0.42$ & cef & $36.00 \pm 1.08$ & efg \\
\hline Jul & $19.83 \pm 0.38$ & $a b$ & $19.68 \pm 0.38$ & $\mathrm{~d}$ & $37.16 \pm 0.77$ & eg \\
\hline Aug & $19.16 \pm 0.80$ & $\mathrm{a}$ & $19.45 \pm 0.66$ & $\mathrm{~d}$ & $37.70 \pm 0.45$ & e \\
\hline Sep & $18.85 \pm 0.63$ & $\mathrm{a}$ & $20.43 \pm 0.71$ & $\mathrm{df}$ & $31.41 \pm 1.10$ & $\mathrm{~d}$ \\
\hline Oct & $20.18 \pm 0.88$ & $a b$ & $22.12 \pm 0.35$ & def & $32.70 \pm 1.07$ & $\mathrm{~cd}$ \\
\hline Nov & $19.18 \pm 1.16$ & $\mathrm{a}$ & $22.68 \pm 1.16$ & def & $35.25 \pm 2.76$ & abfg \\
\hline Dec & $23.15 \pm 1.93$ & $\mathrm{~b}$ & $24.85 \pm 0.79$ & abce & $33.66 \pm 1.53$ & abcdf \\
\hline Depths & $\mathrm{BT} \pm \mathrm{SD}$ & Dunn & $\mathrm{ST} \pm \mathrm{SD}$ & Dunn & $\mathrm{BS} \pm \mathrm{SD}$ & Dunn \\
\hline $5 \mathrm{~m}$ & $23.11 \pm 2.78$ & $\mathrm{~b}$ & $23.84 \pm 3.10$ & \multirow{8}{*}{$\mathrm{p}>0.05$} & $33.69 \pm 2.58$ & \multirow{8}{*}{$\mathrm{p}>0.05$} \\
\hline $10 \mathrm{~m}$ & $21.98 \pm 2.27$ & $a b$ & $23.65 \pm 2.76$ & & $34.50 \pm 2.08$ & \\
\hline $15 \mathrm{~m}$ & $21.18 \pm 2.47$ & $a b c$ & $23.29 \pm 2.72$ & & $34.52 \pm 2.24$ & \\
\hline $20 \mathrm{~m}$ & $20.16 \pm 1.54$ & $a b c$ & $23.56 \pm 2.56$ & & $34.44 \pm 1.95$ & \\
\hline $25 \mathrm{~m}$ & $20.09 \pm 1.48$ & $\mathrm{ac}$ & $23.56 \pm 2.72$ & & $34.55 \pm 1.69$ & \\
\hline $30 \mathrm{~m}$ & $19.39 \pm 1.18$ & c & $23.24 \pm 2.64$ & & $34.97 \pm 2.31$ & \\
\hline $35 \mathrm{~m}$ & $19.55 \pm 1.27$ & c & $23.81 \pm 2.89$ & & $35.05 \pm 1.98$ & \\
\hline $40 \mathrm{~m}$ & $19.01 \pm 1.22$ & c & $23.06 \pm 2.80$ & & $35.36 \pm 1.96$ & \\
\hline
\end{tabular}

$\square$ Class A (\%) $\square$ Class B (\%) $\bullet$ Class C (\%) • Organic-matter $\Delta$ Phi

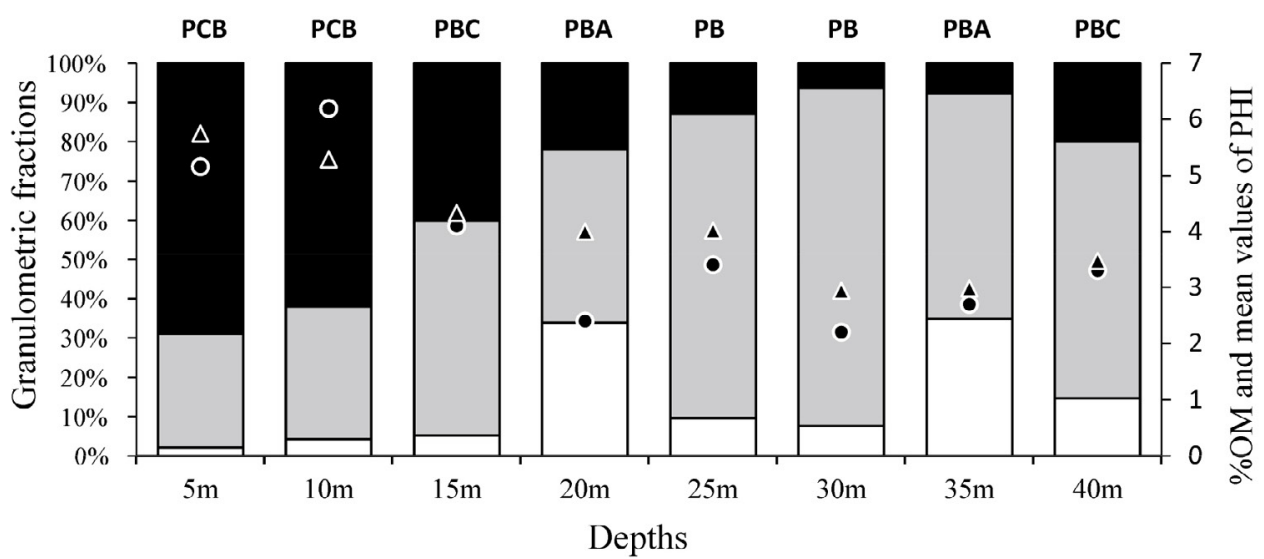

Figure 4. Percentages of granulometric classes and mean values of organic matter in the depths sampled at Ubatuba. A: Class A (gravel, very coarse sand, coarse and medium). B: Class B (fine and very fine sand). C: Class C (silt + clay). 
$\mathrm{m}$ ), while adults of both sexes were more abundant at 20-25 $\mathrm{m}$ of depth (Figure 5). The abundance of juveniles was not correlated with any depth (Figure 6a). Temporally, the lowest abundance of all demographic groups occurred in summer, while in winter and spring the abundance of adults was very high (Figure 5 and Figure $6 \mathrm{~b}$ ).

The RDA indicated, in axis 1 (67.55\%), a positive correlation between juveniles and bottom temperature, phi, and organic matter, and a negative correlation with salinity. Adults, however, were negatively correlated with bottom temperature, phi, and organic matter, and positively with bottom salinity (Figure 7).

\section{$\square$ Juveniles $\square$ Males $\boldsymbol{\square}$ Females}

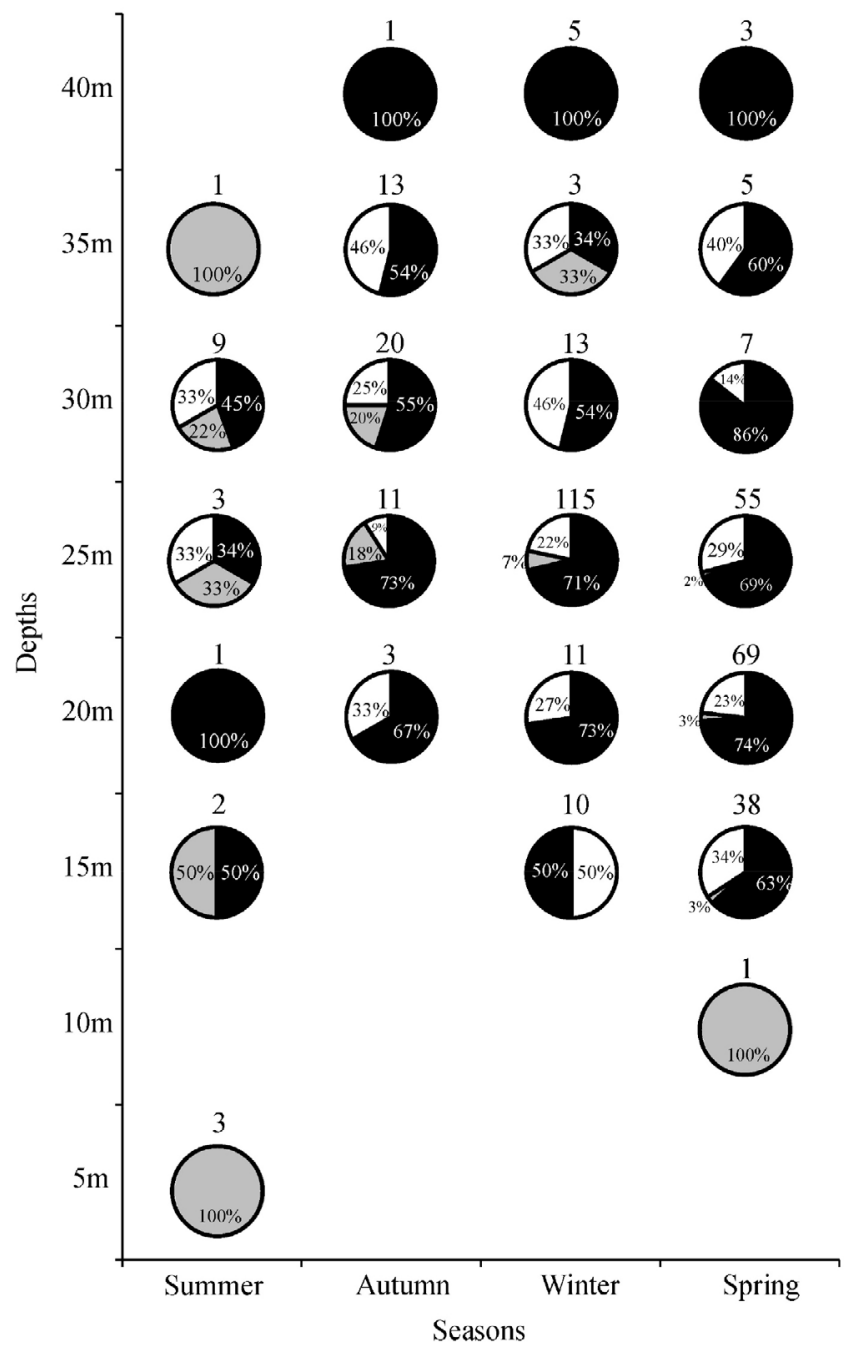

Figure 5. Distribution of demographic groups (juveniles, adult males and adult females) of Achelous spinimanus in the seasons and depths sampled. The number under the circle represents the total collected at the depth and season of the year. 
a)

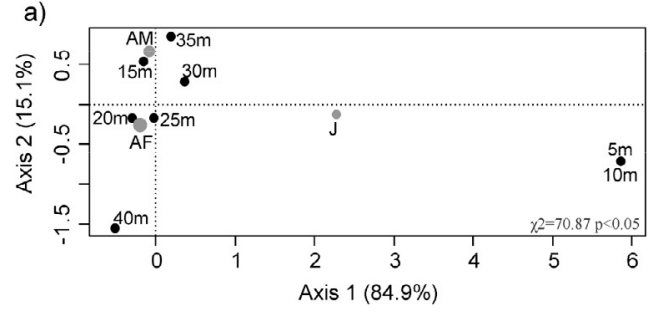

b)

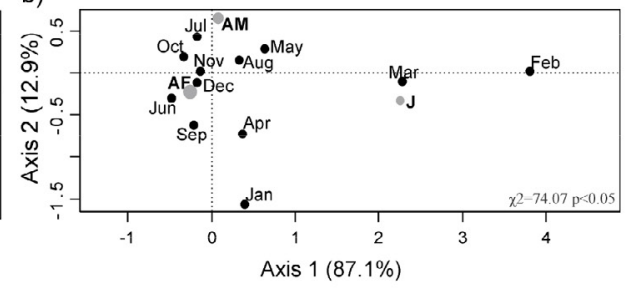

Figure 6. Correspondence Analysis of the abundance of demographic groups ( $\mathrm{AF}=$ adult females, $\mathrm{AM}=$ adult males, $\mathrm{J}=$ juveniles) of Achelous spinimanus by depths (A) and months (B).

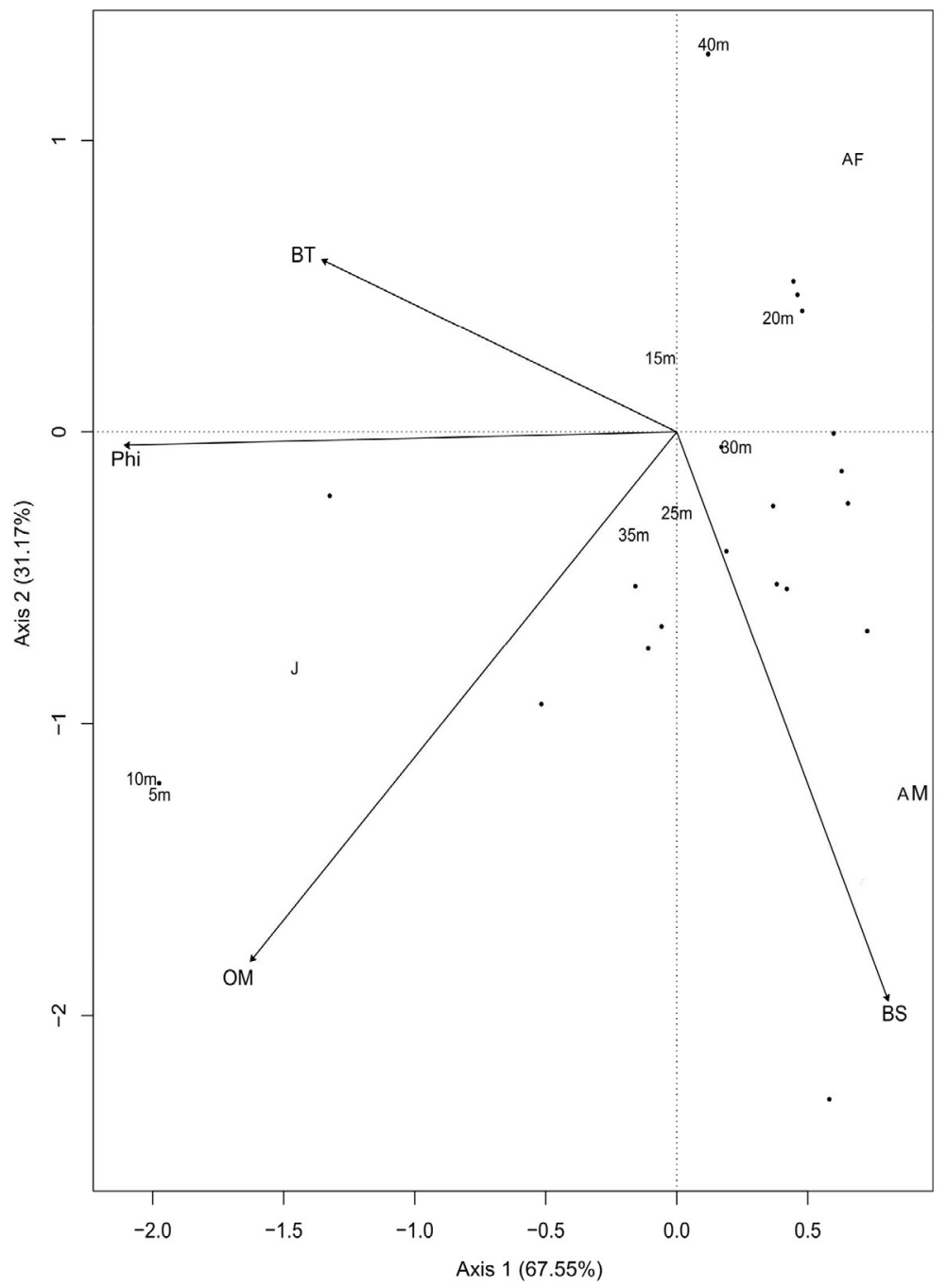

Figure 7. Redundancy Analysis (RDA) between the demographic groups of Achelous spinimanus (legend in figure 6) and the environmental variables (BT= bottom temperature; BS= bottom salinity; Phi; OM= organic matter). 


\section{Discussion}

Our results showed that juveniles and adults of A. spinimanus were distributed differentially between depths and months. In Ubatuba, sediment characteristics change according to depth. Due to this change, plus other environmental factors and interspecific interactions, various benthic species of this region are distributed and adapted to certain depth ranges (Bertini and Fransozo, 2004b). The variation in sediment texture and water temperature and salinity are explained by the hydrodynamic regime of Ubatuba, as indicated by our results (Mahiques et al., 1998). The interior area of the bay (5-15 $\mathrm{m}$ of depth) is composed of fine sediments with a high amount of silt + clay. This occurs due to the bay's low hydrodynamism, which favors the deposition of fine sediments (Mahiques et al., 1998). On the other hand, sites with depths of $20 \mathrm{~m}$ and below are situated offshore, in a region without physical obstacles and strongly influenced by currents. There, the sediment texture is more heterogeneous and fine/very fine sand predominates, and the amount of organic matter is lower (Bertini et al., 2003). In studies by Santos et al. (1994), Bertini and Fransozo (2004b) and Mantelatto et al. (2016), the swimming crab A. spinimanus was more abundant where the substrate was more heterogeneous. This fact explains its higher abundance, in this study, in regions over $20 \mathrm{~m}$ of depth. According to Williams (1984), crabs choose sites where their respiratory capacity is not impaired, and by the presence of sites of easier burial. Substrates composed only of very fine sediment, with a high amount of silt + clay, reduce the capacity to pump water to the gills. Thus, some crab species prefer more heterogeneous substrates.

The RDA showed that water temperature seems to modulate the temporal distribution of A. spinimanus demographic groups. The temporal variation of water temperature observed in this study may be related to the seasonal influence of the SACW, since a thermal amplitude occurred from January to March, i.e., when the region is under its influence. This thermocline has already been described by Pires (1992), Bertini et al. (2001) and Hiroki et al. (2011) along the northern coast of São Paulo. The SACW arrives in the region of Ubatuba, coming from deeper regions. It reaches up to 15 meters in late spring and early summer, causing changes in temperature and salinity, and increasing the primary productivity (Odebrecht and Castello, 2001; Lopes et al., 2006).

The changes caused by the arrival of the SACW seem to trigger a seasonal migration of adults to regions where environmental conditions were more favorable to their establishment. Mantelatto et al. (2016) found a higher abundance of A. spinimanus in spring and summer in sheltered locations of Ubatuba, where there was little influence of this water mass. This seasonal migration helps to explain the low abundance of adults in the first semester of sampling. As of July (winter), when the region was no longer under SACW influence, the abundance of adult $A$. spinimanus increased at all sampling sites, especially at $20-25 \mathrm{~m}$ of depth, probably due to the adults' return from the sheltered areas of the bay. However, juveniles were distributed in several depths, including the shallower areas. Thus, the SACW had less in- 
fluence on this group and also caused a direct relationship between the abundance of juveniles and the high bottom temperatures of these places.

In addition to the influence of temperature, the RDA indicated that adult abundance was positively correlated to salinity, whereas juvenile abundance was negatively correlated to salinity. Thus, juveniles had a wider distribution and occurred from deeper to shallower areas. The shallow areas have a greater variation in salinity due to freshwater supply from the continent. Adult males and females were more abundant in deeper areas where there was little variation in salinity. Thus, adults of both sexes were related to greater depths in the CA, the males at $15 \mathrm{~m}$ and the females at $20-25 \mathrm{~m}$. This result suggests that at this development stage both sexes have practically the same environmental requirements.

Another factor that seems to modulate the presence of juveniles in shallower areas is the sediment's high organic matter content. According to Hines et al. (1987), the high number of juveniles at shallower depths may be related to the greater availability of shelter and food. A higher abundance of juveniles at lower depths was also observed by Santos et al. (1995) with A. spinimanus, Heck et al. (2001) with Callinectes sapidus Rathbun 1896, Andrade et al. (2014) with C. ornatus and Antunes et al. (2015) with C. danae.

The distribution of all demographic groups of this species seems to be modulated not only by environmental factors, but also by interspecific interactions. According to Bertini and Fransozo (2004b) the swimming crabs A. cribrarius, C. danae, and C. ornatus are very abundant in the depths of 5-15 m (inside the bay). Moreover, C. danae and C. ornatus show agonistic behavior and territorialism, which hinders the establishment of other species (Andrade et al., 2014, Antunes et al., 2015). Thus, adults of $A$. spinimanus may have settled mainly outside the bay (at $20 \mathrm{~m}$ of depth and below) to avoid competition with these species.

To conclude, this study showed that, as reported for C. ornatus (Andrade et al., 2014) and C. danae (Barreto et al., 2006 and Antunes et al., 2015), juveniles and adults of $A$. spinimanus were distributed differently between depths and months, corroborating our hypothesis. Juveniles were widely distributed, from shallower areas $5 \mathrm{~m}$ deep to areas $35 \mathrm{~m}$ deep, and were more abundant in summer, whereas adults were more abundant at greater depths $(20-25 \mathrm{~m})$, in winter and spring.

\section{Acknowledgments}

The authors extend their thanks to the many colleagues from the NEBECC group who helped us with sampling and laboratory analysis. We are thankful the anonymous reviewers and the editor for the suggestions in the manuscript The authors are grateful to the São Paulo Research Foundation (FAPESP) for providing financial support (\# 97/12106-3; \# 94/4878-8; 97/12108-6; 97/12107-0 and 98/3134-6) and the Instituto Brasileiro do Meio Ambiente e dos Recursos Naturais Renováveis (IBAMA) for granting permission for the sampling. 


\section{References}

ALMEIDA, A.C.; BAEZA, J.A.; FRANSOZO, V.; CASTILHO, A.L.; FRANSOZO, A. 2012. Reproductive biology and recruitment of Xiphopenaeus kroyeri in a marine protected area in the Western Atlantic: implications for resource management. Aquatic Biology, 17(1): 57-69. https://doi.org/10.3354/ab00462

ANDRADE, L.S.; COSTA, R.C.D.; CASTILHO, A.L.; FRAMESCHI, I.F.; SANCINETTI, G.S.; FRANSOZO, A. 2017 Reproductive and population traits of the swimming crab Achelous spinimanus (Crustacea: Decapoda) in an upwelling region in southeastern Brazil. Nauplius, 25: 1-11. http://dx.doi.org/10.1590/2358-2936e2017004

ANDRADE, L.S.; BERTINI, G.; FRANSOZO, V.; TEIXEIRA, G.M.; BARROS-ALVES, S.P.; FRANSOZO, A. 2014. Differential occupation of habitat as a reproductive strategy of the blue crab Callinectes ornatus Ordway, 1863 (Crustacea: Decapoda). Marine Biodiversity, 44: 27-36. http://10.1016/j.csr.2014.12.005

ANTUNES, M.; FRANSOZO, V.; BERTINI, G.; TEIXEIRA, G.M.; FRANSOZO, A. 2015. Abundance and distribution of the swimming crab Callinectes danae Smith, 1869 (Crustacea, Decapoda, Portunidae) in the Ubatuba region, southeastern Brazil. Marine Biology Research, 11: 920-932. https://doi.org/10.1080/17451000.2015.1044998

BARRETO, A.V.; BATISTA-LEITE, L.M.A.; AGUIAR, M.C.A. 2006. Maturidade sexual das fêmeas de Callinectes danae (Crustacea, Decapoda, Portunidae), nos estuários dos rios Botafogo e Carrapicho, Itamaracá, PE, Brasil. Iheringia, 96(2): 141-146. https://doi. org/10.1590/s0073-47212006000200003

BERTINI, G.; FRANSOZO, A. 2004a. Biodiversity of brachyuran crabs (Crustacea: Decapoda) from non-consolidated sublittoral bottom on the northern coast of São Paulo State, Brazil. Biodiversity and Conservation, 13: 2185-2207. https://doi.org/10.1023/ B:BIOC.0000047900.96123.34

BERTINI, G.; FRANSOZO, A. 2004b. Bathymetric distribution of brachyuran crab (Crustacea, Decapoda) communities on coastal soft bottoms off southeastern Brazil. Marine Ecology Progress Series, 279: 193-200. https://doi.org/10.3354/meps279193

BERTINI, G.; FRANSOZO, A.; BRAGA, A.A. 2003. Ecological distribution and reproductive period of the hermit crab Loxopagurus loxochelis (Anomura, Diogenidae) on the northern coast of São Paulo State, Brazil. Journal of Natural History, 38(18): 2331-2344. https://doi.org/10.1080/00222930310001625905

BERTINI, G.; FRANSOZO, A.; COSTA, R.C. 2001. Ecological distribution of three species of Persephona (Brachyura: Leucosiidae) in the Ubatuba region, Sao Paulo, Brazil. Nauplius, 9(1): 31-42.

BERTINI, G.; FRANSOZO, A.; NEGREIROS-FRANSOZO, M.L. 2010. Brachyuran softbottom assemblage from marine shallow waters in the southeastern Brazilian littoral. Marine Biodiversity, 40: 277-291. https://doi.org/10.1007/s12526-010-0049-9

BOSCHI, E.E. 2000. Species of decapod crustaceans and their distribution in the American marine zoogeographic provinces. Revista de Investigación and Desarrollo Pesquero, 13: 7-136.

BRAGA, A.A.; FRANSOZO, A.; BERTINI, G.; FUMIS, P.B. 2007. Bathymetric distribution and recruitment of the spider crab Libinia spinosa $\mathrm{H}$. Milne Edwards 1834 in the 
Ubatuba and Caraguatatuba regions, northern coast of São Paulo, Brazil (Crustacea, Brachyura, Majoidea, Pisidae). Senckenbergiana biológica, 87: 7-16.

BRANCO, J.O.; LUNARDON-BRANCO, M.J. 2002. Ecologia trófica de Portunus spinimanus Latreille, 1819, na Armação do Itacoporoy, Penha, Santa Catarina. Revista Brasileira de Zoologia, 19:723-729. https://doi.org/10.1590/s0101-81752002000300009

DE-CARLI, B.P.; SEVERINO-RODRIGUES, E.; ROTUNDO, M.M.; MUSIELLO-FERNANDES, J.; ANCONA, M.C. 2016. Fecundidade e morfometria de Achelous spinimanus (Latreille, 1819) (Brachyura, Portunidae) capturado no litoral do estado de São Paulo, Brasil. Boletim do Instituto de Pesca, 40(4): 487-495.

FANTUCCI, M.Z.; BIAGI, R.; MEIRELES, A.L.; MANTELATTO, F.L.M. 2009. Influence of biological and environmental factors on the spatial and temporal distribution of the hermit crab Isocheles sawayai Forest \& Saint-Laurent, 1968 (Anomura, Diogenidae). Nauplius, 17(1): 37-47.

FRANSOZO, A.; SOUZA, A.N.; RODRIGUES, G.F.B; TELLES, J.N.; FRANSOZO, V.; NEGREIROS-FRANSOZO, M.L. 2016. Crustáceos decápodes capturados na pesca do camarão-sete-barbas no sublitoral não consolidado do litoral norte do estado de São Paulo, Brasil. Boletim do Instituto de Pesca, 42(2): 369- 386. https://doi.org/10.20950/ 1678-2305.2016v42n2p369

GUILLORY, V.A.; MCMILLEN-JACKSON, A.L.; HARTMAN, L.; PERRY, H.; FLOYD, T.; WAGNER, T.G.; GRAHAM, G. 2001. Armadilhas de remoção de caranguejo azul e programas de remoção de armadilhas. Publicação da Comissão das Pescas Marinhas dos Estados do Golfo. Mississippi, Ocean Springs, p. 13.

HECK, JR. K.L.; COEN, L.D.; MORGAN, S.G. 2001. Pre- and post-settlement factors as determinants of juvenile blue crab Callinectes sapidus abundance: Results from the north-central Gulf of Mexico. Marine Ecology Progress Series, 222: 163-176. https://doi. org/10.3354/meps222163

HINES, A.H.; LIPCIUS, R.N.; HADDON, A.M. 1987. Population dynamics and habitat partitioning by size, sex and molt stage of blue crabs Callinectes sapidus in a subestuary of central Chesapeake Bay. Marine Ecology Progress Series, 36: 55-64. https://doi. org/10.3354/meps036055

HIROKI, K.A.N.; FRANSOZO, A.; COSTA, R.C.; CASTILHO, A.L.; SHIMIZU, R.M.; ALMEIDA, A.C.A.; FURLAN, M. 2011. Bathymetric distribution of the shrimp Rimapenaeus constrictus (Stimpson, 1874) (Decapoda, Penaeidae) in two locations off the southeastern Brazilian coast. Marine Biology Research, 7: 176-185. https://doi.org/10.1080/1745 1000.2010.489614

LIMA, P.A.; ANDRADE, L.S.; ALENCAR, C.E.R.D.; PEREIRA, R.T.; TEIXEIRA, G.M.; FRANSOZO, A. 2014. Two species of swimming crabs of the genus Achelous (Crustacea, Brachyura): environmental requirements determining the niche. Hydrobiologia, 727: 197-207. https://doi.org/10.1007/s10750-014-1803-y

LOPES, R.M.; KATSURAGAWA, M.; DIAS, J.F.; MONTÚ, M.A.; MUELBERT, J.H.; GORRI, C.; BRANDINI, P.F. 2006. Zooplankton and ichthyoplankton distribution on the southern Brazilian shelf: an overview. Scientia Marina, 70(2): 189-202. https://doi. org/10.3989/scimar.2006.70n2189 
MAGLIOCCA, A.; KUTNER, A.S. 1965 Sedimentos de fundo da Enseada do Flamengo, Ubatuba, SP. Contribuições do Instituto Oceanográfico, 198: 1-15.

MAHIQUES, M.M. 1995. Dinâmica sedimentar atual nas enseadas da região de Ubatuba, Estado de São Paulo. Boletim do Instituto Oceanográfico, 43: 111-122. https://doi. org/10.1590/s0373-55241995000200003

MAHIQUES, M.M.; TESSLER, M.G.; FURTADO, V.V. 1998. Characterization of energy gradient in enclosed bays of Ubatuba region, South-eastern Brazil. Estuarine, Coastal and Shelf Science, 47: 431-446. https://doi.org/10.1006/ecss.1998.0368

MANTELATTO, F.L.M.; FRANSOZO, A.; NEGREIROS-FRANSOZO, M.L. 1995. Distribuição do caranguejo Hepatus pudibundus (Herbst, 1785) (Crustacea, Decapoda, Brachyura) na Enseada da Fortaleza, Ubatuba, SP, Brasil. Boletim do Instituto Oceanográfico, 43(1): 51-61. https://doi.org/10.1590/s0373-55241995000100005

MANTELATTO, F.L.M.; FRANSOZO, A. 1999. Characterization of the physical and chemical parameters of Ubatuba Bay, northern coast of São Paulo State, Brazil. Revista Brasileira de Biologia, 59: 23-31. https://doi.org/10.1590/s0034-71081999000100004

MANTELATTO, F.L.M.; BIAGI, R.; FARIA, F.C.R.; MEIRELES, A.L.; MELO, G.A.S. 2004. Checklist on brachyuran fauna (Decapoda) from infralittoral rocky/sandy bottom of Anchieta Island, São Paulo State, Brazil. Nauplius, 12(2): 135-142.

MANTELATTO, F.L.; BERNARDO, C.H.; SILVA, T.E.; BERNARDES, V.P.; COBO, V.J.; FRANSOZO, A. 2016. Composição e distribuição de crustáceos decápodos associados à pesca do camarão-sete-barbas Xiphopenaeus kroyeri (Heller, 1862) no litoral norte do estado de São Paulo. Boletim do Instituto de Pesca, 42(2): 307-326. https://10.20950/ 1678-2305.2016v42n2p307

MELO, G.A.S. 1996. Manual de identificação dos Brachyura (caranguejos e siris) do litoral brasileiro. São Paulo, Plêiade/FAPESP, 604 p.

NEGREIROS-FRANSOZO, M.L.; FRANSOZO, A.; PINHEIRO, M.A.A.; MENTELATTO, F.L.M.; SANTOS, S. 1991. Caracterização física e química da Enseada de Fortaleza, Ubatuba, P. Revista Brasileira de Geociências, 2(2): 114-120. https://doi.org/10.25249/03757536.1991114120

NENADIC, O.; GREENACRE, M. 2007. Correspondence Analysis in R, with two- and three-dimensional graphics: The ca package. Journal of statistical software. 20: 163-170. https://doi.org/10.18637/jss.v020.i03

ODEBRECHT, C.; CASTELLO, J.P. 2001. The convergence ecosystem in the southwest Atlantic. In Coastal marine ecosystems of Latin America. Springer Berlin Heidelberg, 147165. https://doi.org/10.1007/978-3-662-04482-7_12

OKSANEN, J.; BLANCHET, F.G.; KINDT, R.; LEGENDRE, P.; MINCHIN, P.R.; O'HARA, R.B.; SIMPSON, G.L.; SOLYMOS, P.; HENRY, M.; STEVENS, H.; WAGNER, H. 2013. Vegan: Community Ecology Package. R package version 2.0-7. http://CRAN.R-project. org/package= vegan

PIRES, A.M.S. 1992. Structure and dynamics of benthic megafauna on the continental-shelf offshore of Ubatuba, southeastern Brazil. Marine Ecology Progress, 86: 63-76. https:// doi.org/10.3354/meps086063 
RIPOLI, L.V.; FERNANDES, J.M.; ROSA, D.D.M.; ARAUJO, C.C.V. 2007. Dinâmica populacional de Portunus spinimanus Latreille, 1819 (Crustacea, Portunidae) em um trecho litorâneo da Ilha do Frade, Vitória-ES. Boletim do Instituto de Pesca, 33(2): 205-212.

SANTOS, S. 2000. Influência dos fatores ambientais na abundância de Portunus spinimanus Latreille, 1819 (Crustacea, Brachyura, Portunidae) na enseada da Fortaleza, Ubatuba, SP. Ciência e Natura, 22: 129-144. https://doi.org/10.5902/2179460x27115

SANTOS, S; NEGREIROS-FRANSOZO, M.L. 1999 Reproductive cycle of the swimming crab Portunus spinimanus Latreille, 1819 (Crustacea, Decapoda, Brachyura) from Ubatuba, São Paulo, Brazil. Revista brasileira de Zooogia, Curitiba, 16(4): 1183-1193. https:// doi.org/10.1590/s0101-81751999000400025

SANTOS, S.; NEGREIROS-FRANSOZO, M.L.; FRANSOZO, A. 1995. Morphometric relationships and maturation in Portunus spinmanus Latreille, 1819 (Crustacea, Brachyura, Portunidae). Brazilian Journal of Biology, 55(4): 545-553.

SANTOS, S.; NEGREIROS-FRANSOZO, M.L.; FRANSOZO, A. 1994. The distribution of swimming crab Portunus spinimanus Latreille, 1819 (Crustacea, Brachyura, Portunidae) in Fortaleza Bay, Ubatuba, SP, Brazil. Atlântica, 16: 125-141.

SHIRLEY, M.A.; HINES, A.H.; WOLCOTT, T.G. 1990. Adaptive significance of habitat selection by molting adult blue crabs Callinectes sapidus (Rathbun) within a subestuary of central Chesapeake Bay. Journal of Experimental Marine Biology and Ecology, 140: 107-119. https://doi.org/10.1016/0022-0981(90)90085-q

SILVA, T.E.; ANDRADE, L.S.; FRANSOZO, V.; FREIRE, F.A.M.; FRANSOZO, A. 2018. Population parameters and distribution of Arenaeus cribrarius (Crustacea, Portunoidea), in southeastern brazilian coast. Boletim do Instituto de Pesca, 44(1): 1-9. https://doi. org/10.20950/1678-2305.2018.187

SOUSA, A.N.; BERTINI, G.; TADDEI F.G.; COSTA, R.C.; SILVA T.E.; FRANSOZO A. 2018. Modulating factors of the abundance and distribution of Achelous spinimanus (Latreille, 1819) (Decapoda, Portunoidea), a fishery resource, in Southeastern Brazil. PeerJ, 6: e5720 https://doi.org/10.7717/peerj.5720

WENTWORTH, C.K. 1922. A scale of grade and class terms for clastic sediments. Journal of Geology, 30: 377-392. https://doi.org/10.1086/622910

WILLIAMS, A.B. 1984 Shrimps, lobsters, and crabs of the Atlantic coast of the eastern United States, Maine to Florida. Smithsonian Institution Press, Washington, D.C. 550 p.

ZAR, J.H. 1996. Biostatistical Analysis. Fourth edition. Upper Saddle River, New Jersey, Prentice-Hall. 663 p.

\section{Resumo}

\section{Fatores ambientais modulando a distribuição batimétrica dos grupos demográ- ficos de Achelous spinimanus (Crustacea)}

A distribuição espaço-temporal dos grupos demográficos (juvenis, machos e fêmeas adultas) de Achelous spinimanus foi analisada em relação aos fatores ambientais na região de Ubatuba. Foram realizadas as amostragens de janeiro a dezembro/2000, 
em oito profundidades. Um total de 402 espécimes de A. spinimanus foi coletado. A menor abundância de todos os grupos demográficos ocorreu no verão, enquanto no inverno e na primavera a abundância de adultos foi muito alta. Espacialmente, os juvenis foram amostrados de 5 a $35 \mathrm{~m}$, enquanto os adultos distribuíram-se de 15 a $40 \mathrm{~m}$, sendo a maioria amostrada nos $25 \mathrm{~m}$. A baixa ocorrência de todos os grupos durante o verão deve-se, provavelmente, à chegada da Água Central do Atlântico Sul na região, que provocou a diminuição da temperatura da água e da salinidade, levando a migração dos caranguejos para locais mais abrigados da enseada, onde as condições ambientais eram possivelmente mais favoráveis. A maior ocorrência dos grupos demográficos nos 25 metros se deve ao tipo de sedimento mais heterogêneo, além de evitar a competição com outras espécies mais abundantes em menores profundidades. Portanto, os fatores que modulam a distribuição de A. spinimanus podem ser diferentes dependendo da fase do desenvolvimento ontogenético.

\section{Palavras-chave}

Migração sazonal, SACW, nicho ecológico, relações interespecíficas 